\title{
IMPLEMENTASI ASUHAN KEBIDANAN BERKELANJUTAN (CONTINUITY OF CARE MIDWIFERY) DI WILAYAH KERJA PUSKESMAS GADANG HANYAR KOTA BANJARMASIN (Implementation Of Sustainable Midwise Care (Continuity Of Care Midwifery) In Work Area Gadang Puskesmas Only Banjarmasin City)
}

\author{
${ }^{1}$ Pratiwi Puji Lestari, ${ }^{2}$ Dwi Prelia Wati \\ Universitas Muhammadiyah Banjarmasin, Fakultas Keperawatan dan IImu Kesehatan, \\ Program Studi DIII Kebidanan \\ Email: pratiwipuji@umbjm.ac.id
}

\begin{abstract}
Introduction: Low Birth Weight (LBW) is responsible for more than $50 \%$ of perinatal deaths in the world (Su et al., 2016). The risk of infant death has increased 20-fold in babies born with Low Birth Weight (LBW). More than 20 million babies worldwide are born with LBW and 95.6\% LBW were born in developing countries, for example in Indonesia. (IDHS, 2015) Method: This research uses a descriptive approach with a case study method. This research uses a qualitative approach with a case study method Result:This ongoing midwifery care (COC) model can be provided by midwives. clients who receive midwifery-sustained midwifery care (COC) led by midwives are more likely to have emotional closeness with midwives they know during pregnancy, childbirth and birth. Conclusion: Continuous midwifery care (COC) conducted in a comprehensive physiological cases handled by midwives. By carrying out ongoing midwifery care (COC) as an effort to detect early emergencies and to maintain the health and welfare of mothers and babies.
\end{abstract}

Keywords : Low Birth, Continuity of Care, Midwifery

\begin{abstract}
ABSTRAK
Pendahuluan: Berat Badan Lahir Rendah (BBLR) bertanggung jawab atas lebih dari $50 \%$ kematian perinatal di dunia (1). Risiko kematian bayi meningkat 20 kali lipat pada bayi yang lahir dengan Berat Badan Lahir Rendah (BBLR). Lebih dari 20 juta bayi di seluruh dunia lahir dengan BBLR dan 95.6\% BBLR lahir di negara yang sedang berkembang, contohnya di Indonesia. (SDKI, 2015) Metode: Penelitian ini menggunakan pendekatan deskriptif dengan metode studi kasus. Penelitian ini menggunakan pendekatan kualitatif dengan metode studi kasus Hasil: Model asuhan kebidanan yang berkelanjutan (COC) ini dapat diberikan oleh bidan. klien yang menerima asuhan kebidanan berkelanjutan (COC) yang dipimpin bidan lebih cenderung memiliki kedekatan secara emosional dengan bidan yang mereka kenal selama kehamilan, persalinan dan kelahiran. Kesimpulan: Asuhan kebidanan yang berkelanjutan (COC) yang komprehensif yang dilakukan pada merupakan kasus yang fisiologis yang ditangani oleh bidan. Dengan melaksanakan asuhan kebidanan berkelanjutan (COC) sebagai upaya deteksi dini kegawatan dan untuk menjaga kesehatan serta kesejahteraan ibu dan bayi

Kata Kunci:
\end{abstract}


ISSN 2656-7733

jurnal.polanka.ac.id/index.php/JKIKT

Volume 3 No. 1 (April, 2021)

Kata kunci : BBLR, Continuity of Care, Asuhan Kebidanan

\section{PENDAHULUAN}

Berat Badan Lahir Rendah (BBLR) bertanggung jawab atas lebih dari 50\% kematian perinatal di dunia (Su et al., 2016). Risiko kematian bayi meningkat 20 kali lipat pada bayi yang lahir dengan Berat Badan Lahir Rendah (BBLR). Lebih dari 20 juta bayi di seluruh dunia lahir dengan BBLR dan 95.6\% BBLR lahir di negara yang sedang berkembang, contohnya di Indonesia. (SDKI, 2015), prevalensi BBLR di Indonesia masih tergolong tinggi yaitu $9 \%$ dengan sebaran yang cukup bervariasi pada masingmasing provinsi.Angka terendah tercatat di Bali $(5,8 \%)$ dan tertinggi di Papua (27\%), sedangkan di Provinsi Jawa Tengah berkisar 7\%, termasuk di Kalimantan Selatan, angkanya cukup tinggi walaupun tidak mencapai 5\% (Kementerian Kesehatan Republik Indonesia, 2015).

Berat Badan Lahir Rendah (BBLR) disebabkan oleh banyak faktor kompleks. faktor ibu saat hamil antara lain sebagian besar usia ibu tidak risiko, sebagian besar paritas tidak risiko, sebagian besar status gizi tidak risiko,sebagian besar pendapatan keluarga rendah, sebagian besar pengetahuan tentang ANC baik, sebagian besar kunjungan ANC teratur (Tazkiah et al., 2013).

Selain itu, BBLR dipengaruhi oleh faktor risiko ibu, plasenta dan lingkungan eksternal. Pemenuhan nutrisi pada janin selama masa kehamilan juga sangat menentukan bagaimana outcome persalinan. Bayi dengan berat badan lahir rendah umumnya mengalami proses hidup jangka panjang yang kurang baik. Apabila tidak meninggal pada awal kelahiran, bayi BBLR memiliki risiko tumbuh dan berkembang lebih lambat dibandingkan dengan bayi yang lahir dengan berat badan normal. Selain gangguan tumbuh kembang, individu dengan riwayat BBLR mempunyai faktor risiko tinggi untuk terjadinya hipertensi, penyakit jantung dan diabetes setelah mencapai usia 40 tahun (Bagus Prabowo \& Sutrisna, 2018; Juaria, 2014).

Puskesmas Gadang Hanyar merupakan salah satu Puskesmas di Kota Banjarmasin Kalimantan Selatan yang melaksanakan asuhan kebidanan diantaranya untuk mengelola pencegahan BBLR. Beberapa program terkait gizi ibu hamil seperti pemberian makanan tambahan, suplemen besi, melaksanakan PWS KIA, Pelayanan Antenatal Terpadu, Posyandu, Poskesde terutama dilakukan untuk pencegahan sejak masal kehamilan (Puskesmas Gadang Hanyar, 2019).

Pencegahan juga dilakukan dengan melalui pemeriksaan kehamilan dengan standar pelayanan kehamilan suntik TT, kepemilikan buku kesehatan lbu dan Anak (KIA), pemeriksaan urine, HIV/AIDS dan lainnya, konseling tentang gizi, dan program persalinan dan pencegahan komplikasi (P4K) menggunakan stiker, Serta diberikan imunisasi pada bayi dan balita.

Upaya deteksi dini untuk mengatasi kesakitan dan kematian baik ibu, bayi dan balita dapat dilakukan dengan implementasi asuhan berkelanjutan atau Continuity Of Care (COC) yang komprehensif dimulai dari Pra kehamilan, masa kehamilan, persalinan, nifas, bayi baru lahir, sampai dengan KB.

Tujuan penelitian ini yaitu untuk melihat bagaimana asuhan kebidanan yang berkelanjutan (COC) yang komprehensif dilakukan pada kasus yang fisiologis. Hal ini dimaksudkan untuk menjaga agar ibu sehat selama masa kehamilan, persalinan dan nifas serta mengusahakan bayi yang dilahirkan sehat, mernantau adanya kemungkínan risiko-risiko kehamilan, dan merecanakan penatalaksanaan yang optimal 
terhadap kehamilan risiko tinggi serta menurunkan morbíditas dan mortalitas ibu dan janin perinatal.

\section{METODE PENELITIAN}

Penelitian ini menggunakan pendekatan deskriptif dengan metode studi kasus. Penelitian ini menggunakan pendekatan kualitatif dengan metode studi kasus, Penelitian ini menggunakan pendekatan kualitatif dengan metode studi kasus,

Penelitian dilaksanakan dengan melakukan asuhan kebidanan berkelanjutan (COC) yang komprehensif dimulai tanggal 23 Oktober 2018 sampai dengan 04 Januari 2019 pada pasien Ny.A. Pelayanan asuhan berkelanjutan (COC) yang komprehensif dilakukan di Bidan Praktik Mandiri (PMB) Bldan B di Wilayah Puskesmas Gadang Hanyar Kota Banjarmasin.

Subjek pada penelitian ini adalah ibu hamil dengan usia kehamilan trimester tiga diatas 29 minggu. Peneliti melakukan observasi pada pelaksanaan asuhan kebidanan berkelanjutan (COC) yang komprehensif yang dilakukan pada subjek penelitian dimulai dari kehamilan trimester tiga, persalinan, nifas sampai 6 minggu serta bayi baru lahir. Observasi juga dilakukan dengan mengamati lembar catatan asuhan yang dilakukan. Instrumen penelitian yang digunakan adalah lembar observasi asuhan kebidanan serta dokumentasi.

\section{HASIL DAN PEMBAHASAN}

Telah dilakukan pemeriksaan ANC umur kehamilan 35 minggu ke umur kehamilan 36 minggu sebanyak 2 kali, ibu datang untuk melakukan ANC karena ini kehamilan ibu yang pertama sehingga ibu sangat perhatian dengan janinnya dan juga karena ibu mengeluh saat itu dengan keluhan sering kencing. Dalam pemeriksaan ANC tidak masalah jika ibu melakukan kunjungan sebelum waktunya karena kunjungan ANC pun bagus untuk mengetahui keadaan ibu dan janin. Tetapi seharusnya ibu melakukan kunjungan ulang pada umur kehamilan 36 minggu seperti yang ada diteori sesuai standar pemerintah.

Pemeriksaan semasa kehamilan harus dijadwaikan sejak awal, jadwal pemeriksaan kehamilan dimulai dari hari pertama haid terakhir sampai usia 28 minggu. Dalam usia ini dilakukan 4 minggu sekali. Usia kehamilan 28-37 minggu pemeriksaan dilakukan 2 minggu sekali. Kehamilan 36 minggu: dilakukan pemeriksaan 1 minggu sekali kecuali jika ditemukan kelainan/faktor risiko yang memerlukan penatalaksanaan medik lain, pemeriksaan harus dilakukan ibu lebih sering dan intensif (Mufdlillah, 2009).

Pada pemeriksaan payudara karena pasien malu untuk membuka baju sehingga penulis hanya menanyakan saja, padahal pemeriksaan payudara sangat penting dilakukan jika tidak dilakuakan maka penulis tidak dapat mengetahui bagaimana keadaan payudara ibu apakah ada kelainan atau tidak karena payudara merupakan hal yang paling penting saat proses persalinan untuk sumber nutrisi bayi ibu. Pemeriksaan payudara harus dilakukan untuk memeriksa kebersihannya, putting susu menonjol atau tidak, hiperpigmentasi pada aerola, bekas operasi dan kelenjar Montgomery (Saminem, 2009).

Pada asuhan kehamilan, pemeriksaan genitalia sangat penting dilakukan apalagi untuk kunjungan pertama di trimester tiga. Pemeriksaaan genetalia dilakukan untuk mengetahui adanya tukak/luka, varises, cairan (warna, konstitensi, jumlah dan bau), kelenjar bartholini (pembengkakan, massa atau kista dan cairan) jika ditemukan salah satu tanda bahaya tersebut maka bidan segera melakukan pemeriksaan yang lebih 
lanjut (Hani, 2010). Pada kunjungan pertama atau kontak pertama dengan subjek penelitian (ibu hamil) pemeriksaan genitalia tidak dilakukan, hal tersebut disebabkan karena subjek penelitian merasa risih dan enggan untuk membuka pakaian untuk pemeriksaan. Dalam hal ini, faktor psikis menjadi poin penting, bidan harus terlebih dahulu membangun trust dengan ibu hamil, sehingga akan mengurangi rasa cemas, enggan dan mempercayai bidan untuk melakukan pengkajian data selengkap lengkapnya. Terlebih lagi subjek penelitian merupakan primipara. Dari penelitian dikemukakan bahwa ibu hamil primipara cenderung memiliki risiko kecemasan yang lebih besar dibanding dengan ibu hamil multipara (Na'Im, 2010).

Keluhan umum yang terjadi pada trimester tiga dialami subjek penelitian adalah sering kencing. Untuk menanggulangi keluhan tersebut, bidan melakukan konseling keluhan fisiologi pada trimester tiga. Pengaruh desakan hamil muda dan turunnya kepala bayi pada hamil tua, terjadi gangguan miksi dalam bentuk sering berkemih. Desakan tersebut menyebabkan kandung kemih cepat terasa penuh. Hemodilusi menyebabkan metabolisme air makin lancar sehingga pembentukan urine akan bertambah (Prawiroharjo, 2010).

Pada kunjungan ANC yang ke 3, keluhan yang dikemukakan oleh subjek penelitian adalah sakit pinggang. Telah dilakukan konseling penanganan sakit pinggang yang sesuai yaitu dengan mereduksi aktivitas untuk persiapan kehamilan pada saat umur kehamilan ibu 37 minggu. ibu mengeluh sakit pinggang pada teori dijelskan bahwa sakit pinggang merupakan nyeri yang terjadi padaarea lumbosacral. Nyeri punggung bawah biasanya akan meningkat intensitasnya seiring pertambahan usia kehamilan karena nyeri ini merupakan akibat pergeseran gravitasi wanita tersebut dan postur tubuhnya (Vega Swary, 2014). Perubahan ini disebabkan oleh berat uterus yang membesar. Jik wanita tersebut tidak memberi perhatian penuh terhadap postur tubuhnya maka ia akan berjalan dengan ayunan tubuh kebelakang akibat peningkatan lordosis. Lengkungan ini kemudian akan meregangkan otot punggung dan menimbulkan area sakit atau nyeri. Cara mengatasi nyeri bisa dilakukan dengan cara postur tubuh yang baik, hindari membungkuk berlebihan, hindari penggunaan sepatu tumit yang tinggi dan lainnya (Varney, 2002).

Pada proses persalinan kala $\mathrm{I}$ diberikan rendaman rumput Fatimah. Hal ini bertentangan dengan beberapa hasil penelitian yang menunjukkan kerugian dan dampak meminum rendaman rumput fatimah. rumput fatimah dapat menyebabkan bahaya karena Minum rendaman akar rumput fatimah ini akan menimbulkan masalah, Jika mulut rahim belum terbuka, efek kuat kontraksi ini bisa berbahaya. Risikonya dapat menimbulkan pendarahan akibat kontraksi rahim sehingga menyebabkan pecahnya pembuluh-pembuluh darah dan stres otot. Kontraksi yang ditimbulkan akan sangat tinggi, tanpa ada jeda waktu istirahat. Yang sering terjadi, para ibu hamil sudah meminumnya dari rumah. Alhasil, kontraksinya benar-benar kencang. Tapi pembukaannya tidak sesuai dengan kontraksinya. Efeknya berbeda-beda, untuk ibu yang pembukaannya sudah hampir sempurna memang dapat membantu mempercepat kelahiran, namun bagi yang pembukaannya masih awal tentu tidak sesuai dengan kontraksi yang hebat tersebut (Astutik, 2019; Deivita, 2019). Jika tidak tahan akan kontraksi, ibu akan terus-terusan mengejan padahal pembukaan masih sedikit, sehingga besar kemungkinan rahim akan robek. Selain itu akan terjadi perdarahan setelah melahirkan, atau bahkan kematian pada janin.

Pada proses pengeluaran bayi di kala II, episiotomi dilakukan sebagai upaya untuk memperlebar jalan lahir pada proses pelahiran. Dalam hal ini, episiotomy dilakukan dengan indikasi yang sangat subjektif dan kurang tepat dilakukan. Dalam beberapa teori, episiotomi dengan indikasi untuk persalinan dengan tindakan atau instrument (persalinan dengan cunam, ekstraksi dan vakum); untuk mencegah robekan perineum yang kaku atau diperkirakan tidak mampu beradaptasi terhadap regangan yang berlebihan, dan untuk mencegah kerusakan jaringan pada ibu dan bayi pada kasus 
letak / presentasi abnormal (bokong, muka, ubun-ubun kecil di belakang) dengan menyediakan tempat yang luas untuk persalinan yang aman (Cunningham, 1976; Prawiroharjo, 2010; Rahayu, 2016; Varney, 2002).

Saat dilahan bayi tidak dilakukan IMD bayi lahir langsung dikeringkan, dinilai sepintas, jepit ikat potong tali pusat dan kemudian dipindahkan keruang bayi, sementara penulis menyelesaikan kala III. Padahal pada teori seharusnya pada saat proses pelahiran selesai, proses yang baru dimulai, waktu awal ini ketika ibu paling terbuka terhadap bayi baru lahirnya dan bayi berada dalam periode reaktivitas pertamanya sama terbukanya terhadap pengalaman baru paling berharga untuk proses bonding (Varney, 2002).

IMD dilakukan setelah bayi mendapat perawatan bayi (dibersihkan, di beri salep mata dan Vit K). Padahal, IMD yang dianjrkan adalah sesaat setelah lahir sambil menunggu pelahiran plasenta (Varney, 2002). Manfaat inisiasi menyusu dini (IMD) untuk ibu dan bayi yaitu kontak kulit antara ibu dan bayi adalah dada ibu mampu menghangatkan bayi dengan tepat selama bayi merangkak mencari payudara sehingga akan menurunkan kematian karena kedinginan (hypothermia), baik ibu maupun bayi akan merasa lebih tenang, pernapasan dan detak jantung bayi lebih stabil dan bayi akan jarang menangis sehingga mengurangi pemakaian energy, saat merangkak mencari payudara, bayi memindahkan bakteri dari kulit ibunya melalui jilatan dan menelan bakteri menguntungkan dikulit ibu sehingga bakteri ini akan berkembang biak membentuk koloni disusu dan kulit bayi, menyaingi bakteri yang merugikan (Utami, 2015).

Pada saat melakukan asuhan kebidanan pada pasien saat kunjungan 6 jam penulis terlalu banyak memberikan konseling terhadap ibu, padahal seharusnya ibu istirahat yang cukup dan seharusnya penulis tidak harus memberikan konseling yang begitu banyak cukup yang ibu butuhkan saat ini saja seperti kebutuhan nutrisi ibu, istirahat, cara menyusui yang benar karena ibu sudah lelah saat melahirkan sehingga semakin banyak konseling yang diberikan ibu nantinya psikologi ibu terganggu dapat menyebabkan stres dan ibu pun tidak paham juga apa yang disampaikan oleh penulis karena kebanyakan konseling.

Padahal dalam teori selama beberapa hari pertama setelah kelahiran kemampuan ibu baru untuk secara aktif menyerap pengajarannya formal terbatas akibat fokus yang intens pada bayinya yang baru lahir. Pada dasarnya waktu ibu baru mengemukakan bahwa pada dasarnya waktu ibu tersebut berfokus pada bayi dan perilakunya bergantung (fase taking in). Penatalaksanaan puerperium awal adalah (Hidrasi, nutrisi, tingkat aktivitas, medikasi, perawatan puerperium termasuk pemulihan ketidaknyamanan pascapartum, penatalaksanaan ketidakmampuan berkemih, perawatan payudara dan dukungan untuk memilih metode menyusui, uji laboratorium sesuai kebutuhan penapisan $\mathrm{Rh}$ untuk pemberian imunoglobulin $\mathrm{Rh}$ pada ibu $\mathrm{Rh}$ negatif, vaksin rubella untuk wanita nonimun, kontrasepsi jika dimulai sebelum kunjungan pertama pascapartum)(Astuti, 2015; Bahiyatun, 2009; Cunningham, 1976; Kaplan H.I, 1998).

Dan ibu post partum 6 jam ini respon emosi yang dialami mungkin sangat kuat dan penuh semangat, baik pada ibu yang sudah pernah mengalaminya maupun ibu baru. Perubahan psikologis mayor bersifat emosi dan suasana hati ibu tampaknya menjadi barometer yang merefleksikan kebutuhan bayi kan pola menyusu, tidur dan menangis. Ibu baru cenderung mudah kesal dan sangat sensitive. Rasa keseimbangan sangat mudah hilang karena mungkin ibu merasa tertekan dan mudah marah oleh kesalahan kecil. Ibu ulai memperoleh kembali rasa keseimbangan dan menjadi normal kembali antara 6-12 minggu. Kemungkinan faktor yang paling penting untuk dapat mendapatkan kembali normalitas adalah kemampuan ibu untuk dapat tidur sepanjang malam (Varney, 2002) 
Model asuhan kebidanan yang berkelanjutan (COC) ini dapat diberikan di sektor swasta dan publik oleh dokter kandungan, dokter umum dan bidan. Wanita yang menerima asuhan kebidanan berkelanjutan (COC) yang dipimpin bidan lebih cenderung memiliki kedekatan secara emosional dengan bidan yang mereka kenal selama kehamilan, persalinan dan kelahiran, lebih mungkin memiliki kelahiran vagina spontan dan kecil kemungkinannya mengalami analgesia epidural, episiotomi, atau kelahiran dengan bantuan alat. Selain itu juga akan memperoleh kepuasan dan ada kecenderungan ke arah efek penghematan biaya untuk model yang dipimpin bidan (Homer, 2016).

Dari hasil yang didapat, khusus untuk pasien yang mendapat asuhan kebidanan yang berkelanjutan (COC) cenderung merasa puas dengan asuhan kebidanan yang didapatkan. Kontribusi asuhan kebidanan berkelanjutan (COC) juga didapatkan untuk melakukan deteksi dini kegawatdaruratan yang mungkin terjadi selain itu, keterikatan antara bidan dan klien akan terjalin melalui perawatan, kepercayaan dan pemberdayaan lebih mudah dilakukan pada klien sehingga kesinambungan asuhan kebidanan berhasil dicapai. Hal ini memiliki kesamaan dengan sebuah penelitian yang mengidentifikasi dan mensintesis temuan yang menyajikan perspektif klien maternitas yang mendapat asuhan kebidanan yang berkelanjutan (COC) (Perriman et al., 2018).

\section{KESIMPULAN}

Asuhan kebidanan yang berkelanjutan (COC) yang komprehensif yang dilakukan pada Ny A merupakan kasus yang fisiologis yang ditangani oleh bidan. Asuhan dilakukan dari kehamilan trimester tiga hingga nifas enam minggu. Dengan melaksanakan asuhan kebidanan berkelanjutan (COC) sebagai upaya deteksi dini untuk menjaga kesehatan dan kesejahteraan ibu dan bayi, mernantau adanya kemungkínan risiko-risiko kehamilan, dan merecanakan penatalaksanaan yang optimal terhadap kehamilan risiko tinggi serta menurunkan morbíditas dan mortalitas ibu dan janin perinatal. Secara keseluruhan asuhan dilakukan dengan baik. Asuhan yang berkelanjutan (COC) memungkinkan klien merasa lebih puas dengan asuhan yang dapat dari bidan, bidan dapat dengan mudah memberikan perawatan dan melakukan pemberdayaan untuk meningkatkan derajat kesehatan

\section{DAFTAR PUSTAKA}

Astuti, S. (2015). Asuhan Nifas dan Menyusui. Erlangga. p:113--147, 197-198.

Astutik, H. (2019). Mekanisme Kontraksi Sel Miometrium Pada Mencit Bunting Setelah Pemberian Ekstrak Rumput Fatimah (Anastatica hierochuntica L.) Melalui Ekspresi OTR, FP, Cx43, Kadar PGE2 DAN PGF2a. Universitas Airlangga.

Bagus Prabowo, K., \& Sutrisna, E. M. (2018). Association Between Bmi, Age And Pariety With Lwb. Universitas Muhammadiyah Surakarta.

Bahiyatun. (2009). Buku Ajar ASuhan Nifas Normal (Edisi I). Penerbit Buku Kedokteran EGC. p:7-20.

Cunningham, F. G. (1976). Williams Obstetrics (24th ed.). McGraw-Hill Education eBooks.

Deivita, Y. (2019). Pengetahuan Tentang Air Rendaman Rumput Fatimah Dengan Sikap lbu Hamil Trimester lii Untuk Kelancaran Persalinan Di Puskesmas Mopuya Kecamatan Dumoga Utara Kabupaten Bolaang Mongondow. Poltekkes Kemenkes Manado.

Hani, U. (2010). Asuhan Kebidanan pada Kehamilan Fisiologis. Salemba Medika.

Homer, C. S. E. (2016). Models of maternity care: evidence for midwifery continuity of care. Medical Journal of Australia, 205(8), 370-374. 
ISSN 2656-7733

Volume 3 No. 1 (April, 2021)

Juaria, H. (2014). Hubungan antara umur dan paritas ibu bersalin dengan kejadian berat badan lahir rendah. BIDAN INDONESIA, 46.

Kaplan H.I. (1998). Comprehensive Texbook of Psychiatry, William \& Walkins (5th Editio).

Kementerian Kesehatan Republik Indonesia. (2015). Profil Kesehatan Indonesia Tahun 2015.

Mufdlillah. (2009). Antenatal Care Focus. Nuha Medika.

Na'Im, N. J. (2010). Hubungan dukungan keluarga dengan tingkat kecemasan ibu primipara menghadapi persalinan di puskesmas Pamulang Kota Tangerang Selatan.

Perriman, N., Davis, D. L., \& Ferguson, S. (2018). What women value in the midwifery continuity of care model: A systematic review with meta-synthesis. Midwifery, 62, 220-229.

Prawiroharjo, S. (2010). Ilmu Kebidanan (Edisi 3). Bina Pustaka. p: 264-272, 540.

Puskesmas Gadang Hanyar. (2019).

Rahayu, A. P. (2016). Panduan Praktikum Keperawatan Maternitas (Edisi I). Deepublish. p:160-171.

Saminem. (2009). Kehamilan Normal. Penerbit Buku Kedokteran EGC.

Su, Y., Wang, S., Chou, H., Chen, C., Hsieh, W., Tsao, P., Tsou, K., \& Network, I. F. (2016). ScienceDirect Morbidity and mortality of very low birth weight infants in Taiwan d Changes in 15 years: A population based study. 7, 1039-1045. https://doi.org/10.1016/j.jfma.2016.10.011

Tazkiah, M., Wahyuni, C. U., \& Martini, S. (2013). Determinan epidemiologi kejadian BBLR pada daerah endemis malaria di Kabupaten Banjar Provinsi Kalimantan Selatan. Jurnal Berkala Epidemiologi, 1(2), 266-276.

Utami, R. (2015). Mengenal ASI Eksklusif. Trubus Agriwidya.

Varney, H. (2002). Buku Saku Bidan (Edisi I). Penerbit Buku Kedokteran EGC. p: 5051.

Vega Swary, A. (2014). Faktor Faktor Yang Mempengaruhi Ibu Hamil Dalam Mengatasi Keluhan Fisiologis Trimester Tiga. Repositori. 